\title{
Christian-Muslim Relations in Tanzania: A Threat to Future Stability and Peace?
}

\author{
Japhace Poncian \\ Assistant Lecturer, Department of History, Political Science and Development Studies, Mkwawa University \\ College of Education, P. O. Box 2513, Iringa-Tanzania \\ *E-mail of corresponding author: jponcian@muce.ac.tz; jponcian@yahoo.co.uk
}

\begin{abstract}
This paper examines Christian-Muslim relations in Tanzania with a view of establishing whether recent confrontations between Muslims and Christians are a real threat to the future of interfaith relations. The paper gathers information and evidence from secondary sources, and primary sources such as blog posts, personal communications, etc. The findings are that although recent confrontations may seem to challenge the relative peaceful interfaith relations, the cases presented do not give adequate evidence to make a conclusion that the future of Christian-Muslim relations is bleak. The paper concludes that far from being motivated by religious factors, recent confrontations have little to do with religious differences and more to do with political manipulations of religious diversity.
\end{abstract}

Keywords: Christian-Muslim relations, Tanzania, religion, politicisation, religious diversity.

\section{Introduction}

Religion plays a very important role in the daily lives and activities of the people of Tanzania and Africa generally. Although Tanzania is a secular state, the constitution of the United Republic of Tanzania guarantees the freedom of worship to all citizens provided this does not contravene the laws of the land nor interfere with the rights of other people. This is why the practice of religion in Tanzania is part and parcel of individual and societal practice as reflected in many areas such as,

the national anthem, the opening prayer of the Legislative Assembly sessions, taking of oaths (Bible or Quran) of allegiance and faithfulness to the constitution in discharging their duties by holders of major public positions, the national radio, Tanzania Broadcasting Corporation (TBC) begin and close with prayers of both Christian and Islam religions, the existence of a ministerial portfolio dealing with religious affairs (Policy, Coordination and Parliamentary Affairs) under the Prime Minister's Office, religious education being part of school curriculum, examinable and recognized by the National Examination Council of Tanzania and the recognition of some important Muslim and Christian observances as public holidays (Mesaki, 2011, pp. 249-250).

Despite being religiously diverse, Tanzania's citizens have lived together and intermingled in ways that have transcended their religious differences (Magesa, 2007; Mwakimako, 2007). In the first two decades of independence, interfaith relations were relatively harmonious thanks to the secularisation of the state and the socialist policies that emphasised national identity as opposed to ethnic and religious identities. However, it would be wrong to assume that the co-existence of these two major religions means that they have been in harmony with each other. In fact, Muslims and Christians have coexisted peacefully and many times quarrelled and conflicted each other.

This paper examines Christian-Muslim relations in Tanzania with a focus on recent confrontations between followers of these religions in order to determine whether or not this calls for concern over the future stability and peace of Tanzania. It argues that although there seems to be deterioration in Christian-Muslim relations in recent times, the available evidence of Christian-Muslim confrontations in Tanzania do not lead us to conclude that the relations have actually become confrontational and polemical and therefore a threat to future stability and peace. The paper uses academic and other relevant sources (such as personal text messages, talks to friends, media reports and social media discussions, and religious press releases and documents).

The paper is organised in four sections. Section two explores and examines how Christians and Muslims in Tanzania have related to each other over time since the $19^{\text {th }}$ century AD. Section three presents cases of recent Christian-Muslim confrontations followed by an examination of the weight of the confrontations to determine whether or not this calls for concern as far as Christian-Muslim relations are concerned. Finally, a conclusion summarises the main arguments of the paper.

\section{Christian-Muslim relations in Tanzania}

Like elsewhere in Africa, Tanzania societies are very religious in that more than two thirds of the population identify themselves as belonging to one religious group or the other (Mukandala 2006, p. 1). For instance, the 1967 population census showed out of 11,762,915 Tanzanians on the mainland 32 percent were Christians, 30 percent Muslims, and 37 percent belonged to African Traditional Religions (Mukandala 2006; Ndaluka, 2012). 
These data were, however, contentious in that they depicted a decline in the proportion of people identifying themselves as Muslims and a rise in the number of Christians relative to what they were in the 1957 census. The 1957 census indicated that Muslims outnumbered Christians at a ratio of three to two (Issa, 2012). This rapid decline in the number of Muslims in just a period of ten years has been at the heart of the heated debate over who commands majority followership between Christians and Muslims; prompting some radical Muslims to argue that the state deliberately doctored the 1967 census data for reasons best known to it (Issa, 2012). Since then there has never been any formal enumeration based on religious affiliations resulting in the multitude of unofficial and controversial data on Christian-Muslim population in Tanzania. This was one of the reasons for the heated debate between the Muslims and the state regarding the inclusion of religious affiliation in the 2012 population census or else the Muslims would not take part in the activity.

Tanzania has for long been regarded as a successful case in SSA where different religions have peacefully coexisted side by side. To adopt Bjon Moller's characterisation, Tanzania is regarded as "'the dog that did not bark", i.e. as an apparently successful instance of the management of religious diversity without major conflicts' (2006, p. 82). Comparing the cases of Northern Nigeria and Tanzania, Lissi Rasmussen (1993) applauded Christian-Muslim relations in Tanzania as opposed to Northern Nigeria where relations are confrontational. She also recommended Tanzania to be a model for harmonious Christian-Muslim relations (as cited in Goddard 1996; Westerlund 1997). To grasp the complexity of the relations, one needs at least to analyse how Christians and Muslims have related to each other since they first came in contact.

\subsection{Christian-Muslim relations up to 1961}

Relations between Christians and Muslims in Tanzania can be traced as far back as the $19^{\text {th }}$ century when for the first time Islam and Christianity interacted. It is argued that the history of Islam in Tanzania can be traced back to the $9^{\text {th }}$ century and that by the $14^{\text {th }}$ century Islam was widespread along the coast of East Africa (Mukandala, 2006). Islam entered Tanzania through trade relations between the coast and traders from continental Asia. Its spread to the interior of Tanzania was similarly facilitated by trade activities especially during the $19^{\text {th }}$ century when the interior of Tanzania was increasingly penetrated by coastal based Arab traders (Bennett, 1969). Christianity on the other hand entered Tanzania for the first time during the $16^{\text {th }}$ century when the Portuguese invaded the coastal towns (Ndaluka, 2012). However, the spread and penetration of Christianity in Tanzania occurred greatly during the $19^{\text {th }}$ century as missionaries started their work in the country (Mukandala, 2006). These missionaries established some of their first headquarters in a Muslim dominated Zanzibar from where they expanded their activities to the interior. For example, the French Holy Ghost Fathers settled in Zanzibar in 1863 before moving their headquarters to Bagamoyo in 1868 and the Universities Mission to Central Africa (UMCA) settled in Zanzibar in 1864 from where they extended their work to the mainland (Iliffe, 1979). Throughout their interaction at the coast and in the interior, relations between these two religions were generally good. The only source of conflict between Muslim Arab traders and the Christian missionaries was the missionary campaigns against slave trade which meant an economic threat to slave traders (Bennett, 1968).

Relations started changing gradually with the formal colonisation of Tanzania by the Germans and the British during the latter part of the $19^{\text {th }}$ century. During the German colonial period in Tanganyika, both Islam and Christianity spread rapidly and widely to the interior of Tanganyika. The German approach to religion was friendly as they led a secular government. It is also argued that, after suppressing African resistance in Tanga and Pangani, the Germans allied with the learned coastal people, most of whom were Muslims, and made use of them in different administrative activities as Akidas, Liwalis and Jumbes (Iliffe, 1979). They also built secular schools, such as the Tanga School built in 1892, in which they admitted both Christians and Muslims who were open to western education and civilisation (Iliffe, 1979, pp. 208-09).

However, as Christian missionary activities expanded rapidly and widely relations between Christianity and Islam started getting sour though there were no violent confrontations between them. Most Christian missionaries perceived Islam as a threat to the activities of winning African souls to Christ. It was conceived as a threat to be wiped out for Christianity to take hold of Tanganyika. For example, Bishop Vogt of the Holy Ghost Fathers wrote in 1912 that the mission's principal duty at the time was 'to occupy the country by rural schools, in order to close it to Islam and the Protestants' (Kieran, 1966, as cited in Iliffe, 1979, p. 218). This shows how some Christian missionaries were intent on containing Islam. It also shows how complex interreligious relations can be because, as the citation shows, Christian missionaries were themselves competing against and trying to contain each other.

The major tool missionaries used to attract Africans to Christianity was education. They built numerous schools and opened them for admission to Africans on condition that they accept Christianity. Iliffe (1979, p. 224) informs us that primary education expanded greatly in almost every region where missionaries worked mostly during the last ten years of German rule. This expansion, among others, went hand in hand with the incorporation of the converts and the educated into the colonial economy (Iliffe, 1979). This means that Muslims were sidelined in this education development for they could not enrol in missionary schools unless they denied 
their Islamic faith and accepted to be Christianised. This remained unchanged throughout the colonial period.

During the British rule emphasis was put on secular education as a qualification for formal employment implying that Christians were the most privileged for they were the ones who got education in missionary schools (Ndaluka, 2012). This marked the beginning of a Christian-Muslim divide along the lines of education access and achievements, a problem inherited at the time of independence. Despite this discrimination against Muslims, relations between Christians and Muslims remained relatively harmonious. This is proved by the coming together of Christians and Muslims in the struggle for independence through a non-religious political party- the Tanganyika African National Union (TANU) and the election of Julius Nyerere-a Christian- as its president in 1954 by the party's members, majority of whom were Muslims (Ndaluka, 2012, p. 19; Said, 1989).

\subsection{Christian-Muslim Relations, 1961-1985}

It is obvious from the practices of the Christian missionaries during the British colonial period that Tanganyika attained political independence with a society that was characterised by religious discrimination; a society where Christians were both the most educated and employed. This constituted one of the challenges that the independent government of Tanzania had to face and deliberate on. The government took on the challenge and set out to find measures that could transcend religious divides. The aim was to build a unified nation devoid of tribalism and religiosity.

Conscious of this religious divide, the state introduced measures that would guarantee peaceful relations between Christians and Muslims and build a nation of justice, equality, and togetherness. As the government intended, Christians and Muslims generally co-existed peacefully in the whole period of the first regime. Rukyaa (2007, p. 191-2) theorises a number of reasons that may have made this possible:

First, there is a claim that the introduction of Ujamaa ... played an important role. Its philosophy was building a society based on equality, living together, communal ownership of the means of production, and working together. This indirectly weakened the strong feeling of one's affiliation to a particular religion. Tanzanians became accustomed to referring to themselves as Tanzanians rather than Christians or Muslims. Second, right from the beginning the Tanzanian government declared itself secular, so religion had no opportunity to influence state matters. Third, the first president of Tanzania, Julius Nyerere, never deliberately promoted any religious group while he was in power, and upheld the philosophy of equality. Fourth, the government had a good relationship with religious governing bodies. Religious leaders, such as the cardinal, bishops, shaykhs [sic], pastors and priests, have traditionally been highly respected because of their functions. On government social occasions, religious leaders were invited and at times the government would consult them on various matters.

These measures were central in harmonising Christian-Muslim relations during the period under review. Ujamaa for example introduced the nationalisation of all schools and other social services with the view of improving Africans' access to education and other social services; a move that would bridge an education gap that existed between Christians and Muslims and make such service a state responsibility. It is also argued that educated elites of these religions (and those of paganism) were united by two ideologies: nationalism and developmentalism that brought them together in building a developmentalist state during the period from the 1960s to 1980s (Mushi, 2006, p. 53). As religious affiliations remained less significant in the project of nation building, it is not surprising that religious conflicts were relatively absent, only to emerge after the failure of the state to deliver expected development miracles (Mushi, 2006).

Although many scholars (see for example, Moller [2006]; Rukyaa [2007]; Olsson [2011]) have generally credited the Arusha Declaration and its Ujamaa policies for having disbanded potential religious threats, other scholars like Westerlund (1997) argue that Ujamaa's control over freedom of press and speech may have harboured potential religious conflicts. Moreover, most recent radical Muslim writers and the general Muslim community have criticised Julius Nyerere's regime and its policies arguing that it was Nyerere who marginalised Muslims by banning their religious organisations such as the East African Muslims Welfare Society (EAMWS) which, among other things, aimed to build a Muslim University in Tanzania (Said, 1989; MfumoKristo blogspot, 2012). They further argue that the Nyerere regime deliberately favoured Christians and the Roman Catholic Church at the expense of the Muslim community and that even the union between Tanganyika and Zanzibar was engineered by Nyerere as a strategy of containing Islam and Muslims (Said, 1989; al-Zinjibari, n.d.).

Whether or not the Nyerere regime deliberately undermined Islam and Muslims and promoted Christianity and the Church remains open to research. Important to note here is the fact that Muslim-Christian relations during the period under review generally remained less antagonistic. This relative peaceful co-existence of Muslims and Christians started being challenged as the country moved from the policy of socialism to neoliberalism in the $1980 \mathrm{~s}$ 


\subsection{Christian-Muslim Relations, 1985-present}

Many commentators on Muslim-Christian relations in Tanzania are of the view that the period under review witnessed gradual erosion of peaceful relations between these two religions in Tanzania. The abandonment of the policies and ideology of socialism and its replacement with economic and political liberalisation opened space for some freedoms which were once contained under socialism. Open criticism of the state, its policies and practices increased as people became free to air out their views. This is why Rukyaa $(2007$, p. 192) argues that 'the peace enjoyed between Muslims and Christians began to fade from the beginning of the past two decades.' This view is supported by other commentators like Tanner (2012, p. 11), Olsson (2011), Makulilo (2010, p. 4), and Moller (2006, p. 85). Despite the general opinion that interreligious relations are deteriorating, Moller (2006, p. 85) is optimistic when he opines that 'The general picture of Christian-Muslim relations does thus not appear alarming at all.' This is supported by an argument by Tambila (2006, p. 69) that although there is some conflict especially in and around Dar es Salaam and a little in Morogoro and Mwanza, there is general agreement that at the level of a common person, there are generally good relations between Christians and Muslims. This is the argument held by this paper in spite of the following cases which, on the surface, may suggest that the relations have deteriorated.

\section{Cases of recent Christian-Muslim confrontations}

In the recent past, several incidences involving Christians and Muslims have happened in Tanzania. These have taken the forms of confrontation, destruction of property, accusations of favouritism, etc. some of these incidences include the following.

\subsection{Religious discrimination}

The first incidence involves Christians discriminating against Muslims in some social matters. For instance, in the 1990s, Christians in Bukoba and some parts of Tanzania started preventing Muslims from participating in activities like weddings and burial ceremonies (Rukyaa, 2007, p. 192). Some Christian extremists boycotted Muslim shops and some went to the extent of burning clothes decorated with pictures of the great mosque of Mecca or Arabic words (Rukyaa, 2007). This also recently happened in some parts of the country. In Kagera for example, a row over who has right to slaughter animals is reported to have altered social and cultural norms that bind people together to the extent of some radical Sunni Muslims withdrawing themselves from participating in community activities (such as, for example, burial ceremonies, etc).

There are also events involving high ranking political leaders who are blamed for instigating confrontations or conniving to discriminate against another religion. For example, in July 1993 a letter allegedly written by Ali Kighoma Malima-the then Minister of education- was made public (Rukyaa, 2007). It became clear that the letter was advising president Mwinyi to reduce numbers of Christians admitted to university with a claim that Christians were greatly promoted during the first regime and so it was time for Muslims (Rukyaa, 2007). This reflected Muslims' claim that they were being left out in the education system because of their religion, a claim that still attract subscribers in the Muslim cycles even today. The aftermath of the Ali Malima issue, his resignation from the ruling Chama Cha Mapinduzi (CCM), his decision to vie for presidency through an opposition party and his sudden death in London were all decisive in the Christian-Muslim relations. Muslims believed Malima was persecuted by a coordinated Christian lobby group while some Christians allegedly believed Malima was a threat to national security and stability (Said, 2011).

\subsection{Riots and destruction of properties}

In 1993 pork butchers were destroyed by a rioting group of radical Muslims in Dar es Salaam. These riots were instigated by a Sunni Sheikh Yahya of the Quran Development Council of Tanzania (BALUKTA) (Moller, 2006; Rukyaa, 2007). A booklet promoting this move was written and spread by an organization based in Iran, consequently leading to attacks on pork shops in Dar es Salaam on Good Friday in 1993 (Rukyaa, 2007). The consequence of this was to make some Christians to associate Islam with violence (Moller, 2006). The riots and vandalism also prompted the Catholic Church through its Tanzania Episcopal Conference (TEC) to register a claim that the government was not properly dealing with the Muslim radicals; a claim that the then president-Ali Hassan Mwinyi- dismissed and urged the Catholic Church not to meddle in politics (Rukyaa, 2007; Tambila, 2006).

In 1998, Muslim preachers at a mosque in Mwembechai, Dar es Salaam instigated riots under the cover of fighting for Muslim rights resulting in the burning of vehicles and destruction of properties worth some millions of shillings (Rukyaa, 2007, p. 193). In the process of curbing the violence, three Muslims were shot dead by the police (Rukyaa, 2007). This incidence made the Muslim community blame the government for siding with Christians to deny them their God-given right to propagate their religion and also for mishandling the case that resulted in some Muslims being imprisoned while no single Christian was imprisoned (Said, 2011).

In October 2012 there happened a conflict between Christians and Muslims in Dar es Salaam that 
involved a group of Muslims invading Christian churches, squandering church properties and demolishing churches. It was reported that at least seven churches were attacked (Aman, 2012). This however was not the first time churches were vandalised. The ELCT press release mentions a series of church burnings in Zanzibar, Mwanza, Mdaula, Mto wa Mbu, Tunduru, Rufiji, and Kigoma (ELCT, 2012). The Mbagala violent clashes came after scores of Muslim youth stormed a police station in Mbagala, Dar es Salaam demanding a 14 year old boy who defiled the Quran by urinating on it to be handed to them to be beheaded (James, 2012). Interestingly, it is notable that some Muslim leaders advised their followers to calm down arguing that there was no reason to do what they did. For example, the Dar es Salaam Chief Sheikh Alhaj Mussa Salum is quoted to have said:

The incident doesn't need emotions in dealing with. Islam means peace; we can deal with such issues peacefully. This matter involved children. Islam considers age; it shouldn't lead to a breach of peace in our country (as cited in James, 2012, para. 4).

The Church's response to the incidence is also interesting. For example, the Bishops of the Evangelical Lutheran Church in Tanzania (ELCT) on $18^{\text {th }}$ October 2012, urged Christians not to retaliate saying that it was time for fasting and praying for the country's peace. A true Christian is the one who is ready to be persecuted for Christ and the church. We Christians are not ready to kill, persecute, revenge in defence of Christ. Our God is not defended by killing others and vandalising other religions' churches/mosques (ELCT, 2012, para. 11, my own translation).

While Christian clerics were urging their followers not to retaliate following the vandalisation of their churches, some radical Christians were responding, though underground, in ways that are prejudicial. They were texting each other through their mobile phones. One such text message that I received from one close friend of mine reads:

Do not be afraid! Violence by Muslims is the beginning of their failure. Their major weapon is war, ours is prayer through Jesus' name. While they are for their interests, we proclaim the Lord's name that surpasses all names. While they are fighting for the kadhi court, we are marching to heaven. While they are for religiosity, we are for salvation. While they are shedding the blood of the innocents, we are covered by the blood of Jesus....

This shows how some Christians perceive the Muslims; a perception that is in tandem with the Western view of Islam and Muslims.

\subsection{Political campaigns and religionisation of politics}

During the 2010 election campaigns there were propaganda going on in mosques and churches that threatened to turn the elections into a Christian-Muslim conflict. It was in these campaigns that the oppositional CHADEMA was associated with the church just because its presidential candidate is a former Catholic priest. The ruling party tactically used this strategy to weaken the CHADEMA's candidate and as a strategy that would make CHADEMA defensive; this would make the Chama Cha Mapinduzi (CCM) campaign team to accuse CHADEMA of using churches to campaign for their candidate (Ngurumo, 2010). But what happened in 2010 was a culmination of what had happened before 2010.

In 2009, the Catholic Church through its Christian Professionals of Tanzania (CPT) and TEC produced what it called 'Ilani' (Manifesto) with the aim of stimulating debate on matters of national interest for the then upcoming General Election (TEC\&CPT, 2009). It did not aim at directing its followers to vote for a certain party or candidate during the election but rather guided them to think through a number of critical issues it thought were important for the country's development and urged them to use the issues to judge leadership contestants (TEC\&CPT, 2009).

This Catholic Church move was interpreted by Muslims as an attempt to lobby Tanzanians (Christians) to vote for Christian candidates and thus make Tanzania a Christian state (Shura ya Maimamu Tanzania, 2009). Thus, Muslims also decided to produce their guide which urged Muslims to vote for those who would cater for Muslim interests. It required Muslims to participate in the elections as Muslims and put forward Muslim and Islam interests while voting (Shura ya Maimamu Tanzania, 2009.). In other words, one would argue that Muslims were being encouraged to vote for their fellow Muslims who would ensure their interests are catered for. Addressing the first $10^{\text {th }}$ parliamentary meeting, the President made note of the problem arguing that it was eminent during the election campaigns and that he would do everything in his powers to curb it (Ngurumo, 2010). Thus, by the time the General Elections were conducted, the country was already divided for political reasons. The following case helps justify the point:

My constituency has 33 villages. Two villages were of special significance to me. The Kagunga village received me well and gave me many votes in 2005 (I defeated my opponent with a 600 votes margin). ... Most of the residents of this village are Christians.

\footnotetext{
${ }^{1}$ Text message sent to my phone from a Christian friend on 14 November 2012 at 12:06:07 urging me to send it to all Christians. Emphasis added to show how some Christians think of the Muslims.
} 
The Bubango village has more Muslim residents. The residents of this village refused to vote for me in 2005, voting for a candidate from the Civic United Front (CUF) party which they claimed was a Muslim party. They did not even want to see me campaigning there. I was badly defeated. In the whole period of five years I was angry at the villagers and did not go there despite the village sending elders to ask for forgiveness. But what happened in 2010?

While on campaigns in Bubango, I was called to a local mosque. Muslims were told to vote for me because I am a fellow Muslim. The Sheikh told the congregation that they should not bother I did not do anything [in terms of development] to the village; they should vote for me because I am a Muslim. I went to an open meeting and told them that I do not need your votes if you are voting me because of being a Muslim. I got many votes from this village. I was voted because of being a Muslim.

I put more efforts in Kagunga as it was my campaign stronghold. Few days before campaigns, it was Tuesday; I was informed that things had changed in Kagunga. I was shocked and decided to hire a private boat to Kagunga where I reached at $10 \mathrm{pm}$. My friends there told me they were asked in their church not to vote for me because if I make it to the parliament I would bring the kadhi court. I requested to meet religious leaders the next day morning; 11 pastors came (there are so many churches in Kagunga). I asked them a question: is it true that I should not be voted because of my religion? They said those were directives and they had already told their fellow believers. I asked: do you believe in these? Four pastors said they were in support of me. At 10AM, I called an open village meeting and told the villagers that whoever did not want to vote for me because of my religion let him/her do so. I listed all we achieved in Kagunga and told them that if they were not enough to make them elect a parliamentarian, then make decisions using your religious affiliation. When the election results were out in Kagunga, I had won with a slight margin of only 90 votes (from 600 votes in 2005) (Kabwe, 2013, para. 23-26) (My own translation).

This shows how tense the situation was becoming during the period of general elections.

\subsection{Religious vs. national identity}

There has recently been a gradual erosion of long time praised culture of the Tanzanians to affiliate themselves to the nation rather than to their religions or tribal affiliations. For example, it is not surprising now to see Muslims struggling to make sure that the to-be redrafted constitution carters for their interests as Muslims, not as Tanzanians. Similarly, Christians were struggling to make sure that their interests are upheld in the coming constitution. For example, when a constitutional review commission was appointed by the President there were some claims that it had more Muslim members than Christians. It was not that those appointed qualified to be members as other Tanzanians, it was rather the issue of what their religious affiliation was. This is even obvious when one considers the process of electing village/street and ward representatives to the district constitutional review councils. Experience from these elections shows that the contesting and voting processes were purely done on religious basis. Muslims went to vote for their fellow Muslims; similarly, Christians went to vote for their fellow Christians. Some of them even went for the contest in order to reduce the possibility of Muslims or Christians alone taking hold of the process. One friend of mine, a Christian, who entered the contest for nomination, had the following to tell me:

Initially, I did not plan to vie for nomination in the village and ward constitutional council representation. I just entered the contest in order to reduce the possibility of the village and ward being represented by Muslims only....

Allegedly, this process was coordinated from the Mosques and Churches. In all these, national interests were subordinated to religious interests thus raising the question of whether a new constitution that caters for the interests of all would be attained. Thus, as some commentators argue, religious identity is now becoming salient as it is used by people to advance their spiritual, material and political interests across Tanzania (Glickman, 2011, cited in Mesaki, 2011, p. 250).

\subsection{The row over the right to butcher animals}

Clashes have occurred between Muslims and Christians over the right to butcher animals in Tunduma, Mwanza, and Geita. In Geita, for example, a Christian priest, Mathayo Kachila, of the Pentecostal Assemblies of God Tanzania church was killed and 15 others wounded early in 2013 following a row over who has right to butcher cattle for sale (Sumira \& Masinde, 2013). In Tunduma, Mbeya, the conflict over who should slaughter animals was reflected in popular demonstration after a realisation that several cattle were slaughtered by a Christian and distributed to butcheries for sale (Mwanakatwe, 2013). In Kagera, the row over who has right to butcher animals resulted in Christians deciding to start butchering animals for their Christian customers and Muslims for theirs

\footnotetext{
${ }^{1}$ Interview with one of the contestants who entered the contest and was nominated to be one of the representatives for his village and even made it in the ward nomination, $10^{\text {th }}$ April 2013, Iringa.
} 
too. The long cherished practice of Muslims slaughtering livestock and cattle for butchery was now becoming questioned as Christians wanted a legal basis of that. This was made worse by the government statement in Mwanza that Muslims were the ones allowed to butcher animals for business purposes, a statement which angered Christians. If that was to be the case, Christians said, Muslims were also to be required to butcher pork.

\subsection{Accusations of discrimination and marginalisation}

There have been accusations from both Christians and Muslims against each other over the perceived marginalisations and exclusion. For example, an allegedly confidential document directed to all Muslims went viral on the internet through a number of social media. The document exposes what it calls Christian manoeuvres to weaken the current regime whose president and vice president are Muslims. It charges Christians with doing everything in their capacity to paint a bad image on the face of the supposedly committed Muslim public servants. The unfortunate thing about the document is that it associates the oppositional CHADEMA with the Church (Roman Catholic). It goes on urging the Muslim community:

... to understand and analyse these. Also what you hear and see must be analysed carefully so that you do not fall into the trap of hailing Christian Hegemony [Mfumo Kristo] through their party-CHADEMA. Moreover, we urge you to warn our children and urge them to cooperate and work together in counteracting this oppression against Islam and Muslims. Encourage them on the necessity of each one getting ready so that we quicken this duty of defending Islam and Muslims in general, insha Allah. ${ }^{1}$ (My own translation).

Although the authenticity of this document is contestable in that it is anonymous and undated (and may have well been prepared by non-Muslims as propaganda against Islam and Muslims), there is one thing to learn from it: its association of CHADEMA with the church is very common as highlighted earlier. Some Muslims, especially through the social media (notably in a Facebook Group by the name Tanuru la Fikra ${ }^{2}$ ), have been directly associating the party with the church. For example, on a thread posted in the famous social media page in Tanzania, Jamii forums, titled CHADEMA, uislam na waislam! (CHADEMA, Islam and Muslims), out of the 155 (as of $29^{\text {th }}$ March, 2013) comments on the post, 45 comments (29 per cent) directly or indirectly associated CHADEMA with Christianity ${ }^{3}$. Two of the comments read as follows:

The difference is huge. CHADEMA IS A CHRISTIAN PARTY, regional based and hypocritical. Muslims do not like hypocrisy and regionalism; therefore CHADEMA and Muslims cannot trust each other ${ }^{4}$.

I hate CHADEMA more than anything else in this world, and that is why here in Zanzibar people have nothing to do with this party. $99.9 \%$ of Zanzibaris [this is of course an exaggeration given that some Zanzibaris are members of CHADEMA and the data cannot be ascertained] believe CHADEMA is the church and the church is CHADEMA [meaning no difference between the party and the Christian church]. And that is the truth! ${ }^{5}$

There has also been a general perception that one religious group is being favoured by the state at the expense of the other. This feeling relates to access to public educational institutions, public employment (Tambila, 2006) and leadership positions. For example, there has been a feeling by most Muslims that the state favours Christian health facilities through a Memorandum of Understanding that it signed with Christian leaders in the early 1990s and that most leadership positions, and employment in public institutions are dominated by Christians. And where Muslims find their way through, they find themselves at positions that are marginal. This feeling is evident in most Muslim public preachings (Mihadhara) and in the social media. Musoke (2006, p. 497), using an example of articles published in An-nuur, a Muslim weekly, informs us that Muslims accuse the Tanzanian government of discriminating against them in education, employment and several other spheres.

For example, one outspoken Muslim writer, Mohamed Said, gives statistical evidence to show how Muslims have been marginalised in the education sector. He argues that between 1978 and 1981, the number of Muslim pupils selected to join secondary education was less that 25 per cent; and that those who found their way through to the University of Dar Es Salaam accounted for less than 20 per cent of the total registered students during the period from $1969 / 70$ to $1989 / 90$ (Said, 1993, Tables 1, 2, 3 and 5). Furthermore, he argues that

\footnotetext{
${ }^{1}$ Anonymous. Tanbihi Kwa Waislamu Wote, article 15. The document is undated and unsigned, thus making its credibility questionable. For a full document, visit: http://jojothefighter.blogspot.com/2012/10/waraka-kwa-waislamu-wotetanzania.html

${ }^{2}$ This is a group whose most posts are about debates between the ruling party (CCM) followers and those of the oppositional party-CHADEMA. Some posts in this group are purely religious with the intention of equating CHADEMA with Christianity and, often times, regionalism and tribalism. Visit it here: https://www.facebook.com/groups/tanurulafikra/

3 See a post by Kim Kardash in Jamiiforums' Jukwaa la Siasa posted on $27^{\text {th }}$ January 2013. Available at www.jamiiforums.com/jukwaa-la-siasa/391292-chadema-uislam-na-waislam.html

${ }^{4}$ See comment number 27 on a post by Kim Kardash, Ibid.

${ }^{5}$ See comment number 141 , Ibid.
} 
Muslim marginalisation in education was not only in terms of student access to education but also appointments to the Ministry of Education posts. For instance, during the period from 1961 to 1989 only seven Muslims were appointed as Educational Commissioners and Directors in the Ministry of Education as compared to 38 Christians (Said, 1993, Table 6). A quotation from the most recent An-nuur depicts how this features in the minds of Muslims in Tanzania:

There is no such thing as bad omen or devil contributing to religious frictions as claimed to be in Tanzania. If it is bad omen and devil, then it is when you have government institutions working as if they were parishes and catering more for the interests of Christians instead of those of the entire nation as the Muslims have been accusing the National Examination Council of Tanzania [NECTA]. And this devil does not need a ritual specialist or a Sheikh to read Ruq'ya nor Pentecostal priests to cast out the demons. ... Books have recorded... that since the colonial time there were efforts to marginalise Muslims in education. And this was done in different ways. One was through taking Christian students from Christian dominated areas to Muslim dominated areas of Pwani [Coast] and Morogoro; replacing the names of Muslim students and giving such opportunities to Christian students; not selecting well qualified Muslim students and giving such positions to Christian students with low grades .... And all this was possible because the Boards, Committees and panels for selecting students for higher education were occupied by Christians only and sometimes their chairpersons were Christian clerics (Msangi, 2013, p. 6).

Interestingly, Christians also hold this view. For example, they claim that most senior political and civil service positions are held by Muslims especially in the current regime. In one of their recent press releases, Christian clerics, through their Tanzania Christian Forum (TCF), claim that over 90 per cent of senior government leadersthe President, vice president, chief of the state intelligence and security service, the chief justice and inspector general of police- are Muslims (TCF, 2012). They also indicate that two thirds of the members of the constitutional review commission are Muslims (TCF, 2012).

Christians would also argue that the present Christian-Muslim confrontations are a result of the state's failure to contain seeds of deterioration, that the state has just left radical Muslims to conduct their activities freely with severe consequence on interfaith relations (see, for example, press releases by ELCT, 2012; TCF, 2013; TCF, 2012). One of the TCF press releases explicitly states that:

Though the government and its security agencies have been getting information about threats against church leaders, murder, burning of churches, and inciteful messages spread through public preaching, brochures, CDs, and media houses owned by institutions that are known, it has greatly failed to take timely action; they only take action after such incidences have happened. Our government seems to have forgotten the saying that "prevention is better than treatment". This may either indicate how weak state security agencies are or that they are happy with the disappearance of peace in our country. This makes the church in Tanzania believe that the government has a secret agenda against Christianity (TCF, 2013, para 12, emphasis added) (my own translation).

Earlier in February 2013, the TCF Mbeya region had issued a statement that went further requiring the government to appropriately handle the issue or otherwise let the church handle it in its own way. Part of the statement read as follows:

If the government will not take concerted efforts to deal with our claims, we, Christian leaders, will take the initiative of telling our congregation members that the government of the ruling Chama Cha Mapinduzi (CCM) favours Islamic religion and they will decide what to do (TCF Mbeya, 2013, para 17) (my own translation).

This was further reiterated by the March 2013 TCF statement which stated that:

Protection of the citizens is the duty of the government and it is the citizens' constitutional and legal right. If it has failed to protect its citizens, the church wants the government to declare that it has failed so that the church tells citizens to hold the government and their leaders accountable for this failure. If the government won't take stern measures against all this, the church will take the responsibility of telling Christians that the government in power favours one religion; so the church will rethink its relationship with the government (TCF, 2013, para. 14-15) (My own translation).

All these examples and events help show how Christian-Muslim relations have been confrontational in the recent times. But, do these incidences suffice to make us believe that the future of Christian-Muslims relations is bleak and therefore a threat to national stability and peace?

Christian-Muslim relations: a threat to future stability and peace?

On the surface, one may think that the relations have greatly deteriorated and that this calls for concern to check any potential risk that might be embedded in the changing relations. On the critical note, however, the above evidence does not seem to provide strong case to make an argument that the peaceful co-existence of Christians and Muslims in Tanzania is waning and that this threatens national unity, peace and stability. From the above 
analysis and evidence, the following observations can be made about Christian-Muslim relations in Tanzania:

* Evidence of religious conflicts in Tanzania is too meagre to give a true and generalisable picture of Christian-Muslim conflicts in Tanzania. The incidences of conflicts cited above are only found in very few places of Tanzania; thus making it difficult to make an academically sound argument that there is a countrywide religious conflict between Christians and Muslims.

* The supposedly religious conflicts are temporal and sporadic, arising mainly during political events such as elections. Much of the above cited incidences happened close to and/or soon after the General Elections in Tanzania. This implies that the incidences are not religiously motivated; they are rather a reflection of political manipulations of religious diversity by self serving politicians. The association of the oppositional parties (CUF as an Islamic party and CHADEMA as a Christian party) with religion by mainly the ruling CCM politicians is a good example; a strategy devised to make Tanzanians believe that the oppositional parties, if elected, would end up sinking Tanzania into a religious civil turmoil.

This has, partly, helped the ruling CCM benefit from this politicisation of religion by staying in power for over 20 years since the re-introduction of multiparty politics in 1992. That the Kadhi courts issue is resurfacing now and that the government has promised to table a Bill for the establishment of the Kadhi courts during the March, 2015 parliamentary meeting (Pesa Times, 2015), just seven months before the General elections due in October, is a political calculation aimed at teasing Muslims so they can continue supporting the ruling CCM.

* The socio-cultural bonds of the Tanzanians are still too strong to be easily shaken by religious differences. Moreover, the level of religious tolerance among the Tanzanians is still high despite recent conflicts over who has a right to butcher animals. That Muslims and Christians can still conduct their prayers and praise sessions in Mosques and Churches built very close to human settlements without any interference and complaints from non-members is a reflection that Christians and Muslims still co-exist peacefully in Tanzania. Similarly, the fact that Christian preachers have freely been preaching the word of God in upcountry buses from Dar es Salaam without any complaints from non-Christians signifies the high level of religious tolerance and co-existence. Down to the grassroots level, religious conflicts between Muslims and Christians only exist in the media reports; citizens continue to live and intermingle in ways that are too strong to be compromised by religious differences.

* The evidence provided above does not show the diverse nature of Christian-Muslim relations and the divisions within these two major religions. As they are, they suggest that Christians and Muslims (of all denominations) are not in harmony when the reality may not be that. There are so many denominations of Islam and Christianity which are themselves divided in the way they take interfaith relations. Generalising the above incidences as to involve all Christians and Muslims risks giving a false account of Christian-Muslim relations in Tanzania. A careful study of each religion's denominations would help provide an accurate account of varied perceptions on interfaith relations and dialogue.

* As such, there does not appear to be a Christian-Muslim conflict in Tanzania. What has been taking place in the recent times may be characterised as political manipulations of religious diversity for self serving interests of the politicians. It can also be regarded as an ongoing national dialogue over how followers of different religions feel they are treated and what they think should be done to ensure there is equal treatment of all irrespective of one's religious affiliation. There is little to be worried of as far as the future of Christian-Muslim relations is concerned. What may be worrisome however, is the politicisation of religion and religionisation of politics. This is what needs to be discouraged by both the government and religious leaders.

\section{Conclusion}

This paper has examined the evolution of Christian-Muslim relations in Tanzania and the recent ChristianMuslim confrontations with a view of establishing whether the incidences threaten the future stability and peaceful co-existence of Christians and Muslims. The paper has argued that the recent confrontations and incidences involving Christians and Muslims do not seem to paint a negative picture of the future interfaith relations as well as national stability and peace. This is because, the confrontations are generally not motivated by religion but by the political manipulations of religious diversity as well as perceptions of the way the state treat followers of different religions across the socio-economic and political opportunities. The evidence presented is too meagre to warrant a general conclusion that there is indeed a sustained national ChristianMuslim conflict.

\section{References}

Al-Zinjibari, K.M.R. (n.d.). Nyerere Against Islam in Zanzibar and Tanganyika. http://www.muslimpopulation.com/africa/Tanzania/NYERERE\%20AGAINST\%20ISLAM\%20IN\%20ZANZIB AR\%20AND\%20TANGANYIKA.php 
Aman, F. (2012). JK's word on Mbagala violence. The Citizen, October 14. http://www.thecitizen.co.tz/leadstories/26533-jks-word-on-mbagala-violence.html

Bennett, N.R. (1969). “The Arab Impact.' In Zamani: A Survey of East African History, edited by B. A. Ogot and J. Kieran, 216-237. Nairobi: EAPH.

ELCT. (2012). Salaam za Maaskofu wa KKKT kwa Watanzania wote Kuhusiana na Matukio ya Kuchoma Moto Makanisa ya Kikristo Eneo la Mbagala-DSM. http://www.elct.org/news/2012.10.001.html

Goddard, H. (1996). Christian-Muslim Relations in Africa, Lissi Rasmussen, British Academic Press, 1993, xii + 132 pages, $\quad £ 39.50 \quad$ hardback. $\quad$ Reviewing $\quad$ Sociology $\quad$ 9(3). http://www.reading.ac.uk/RevSoc/archive/volume9/number3/9-3r.htm.

Iliffe, J. (1979). A Modern History of Tanganyika. Cambridge: Cambridge University Press.

Issa, M. (2012). Census and Politics in Tanzania: Facts and Figures. xa.yimg.com $/ \mathrm{kq} /$ groups/.../CENSUS +AND +POLITICS +IN+TZ.pdf

James, B. (2012). Chaos hits Dar as boy defiles Quran. The Citizen, October 13. http://thecitizen.co.tz/component/content/article/37-tanzania-top-news-story/26479-chaos-hits-dar-as-boydefiles-quran.html

Kabwe, Z. (2013). Udini uchafu chini ya kapeti. Raia Mwema, Toleo la 282, February 20. http://www.raiamwema.co.tz/udini-uchafu-chini-ya-kapeti

Magesa, L. (2007). Contemporary Catholic Perspectives on Christian-Muslim Relations in Sub-Saharan Africa: The Case of Tanzania. Islam and Christian-Muslim Relations 18 (2): 165-173.

Makulilo, E.B. (2010). Religion Tensions in Tanzania: Christians versus Muslims http://www.academia.edu/992749/RELIGION_TENSIONS_IN_TANZANIA_Christians_VS_Muslims

Mesaki, S. (2011). Religion and the State in Tanzania. Cross-Cultural Communication, 7(2): 249-259.

MfumoKristo blogspot. (2012). Aliyeanzisha Udini Tanzania ni Nyerere. http://mfumokristo.blogspot.com/2012/05/aliyeanzisha-udini-tanzania-ni-nyerere.html

Moller, B. (2006). Religion and Conflict in Africa with a Special Focus on East Africa. DIIS Report 2006:6. http://www.diis.dk/graphics/Publications/Reports2006/RP_06_6_bmo_religion\%20and\%20conflict.pdf

Msangi, O. (2013). Hakuna 'upepo mbaya' wala shetani Tanzania. An-nuur, April 5-11. http://msamu2000.blogspot.com/2013/04/gazeti-la-annuur.html

Mukandala, R. (2006). "Introduction." In Justice, Rights and Worship: Religion and Politics in Tanzania, edited by Rwekaza Mukandala et al., 1-17. Dar es Salaam: E\&D Limited.

Mushi, S.S. (2006). "Conceptual and Historical Perspectives on Religion-Politics Relations." In Justice, Rights and Worship: Religion and Politics in Tanzania, edited by Rwekaza Mukandala et al., 18-56. Dar es Salaam: E\&D Limited.

Musoke, I.K. (2006). "The Relationship between Religion and Employment in Tanzania". In Justice, Rights and Worship: Religion and Politics in Tanzania, edited by Rwekaza Mukandala et al., 496-513. Dar es Salaam: E\&D Limited.

Mwakimako, H. (2007). Christian-Muslim Relation in Kenya: A Catalogue of Events and Meanings. Islam and Christian-Muslim Relations 18 (2): 287-307.

Ndaluka, T.J. (2012). Religious Discourse, Social Cohesion and Conflict: Muslim-Christian Relations in Tanzania. Munster: LIT Verlag.

Ngurumo, A. (2010). Kikwete kachaguliwa kwa udini au siasa? Tanzania Daima, November 21. http://www.freemedia.co.tz/daima/habari.php?id=21267

Olsson, H. (2011). A Secularisation of a Sacred Ideology? Civil Religion and Inter-Religious Relations in Contemporary

http://lup.lub.lu.se/luur/download?func=downloadFile\&recordOId=2157427\&fileOId=2157440

Tanzania.

Pesa Times (2015). House to Table Kadhi Court Bill in March. http://www.pesatimes.co.tz/news/legalenvironment/house-to-table-kadhi-court-bill-in-march

Rukyaa, J.J. (2007). Muslim-Christian Relations in Tanzania with Particular Focus on the Relationship between Religious Instruction and Prejudice. Islam and Christian- $\quad$ Muslim Relations 18(2): 189-204.

Said, M. (1989). Islam and Politics in Tanzania. http://www.islamicpopulation.com/africa/Tanzania/ISLAM\%20AND\%20POLITICS\%20IN\%20TANZANIA.ht $\mathrm{m}$

Said, M. (1993). Intricacies and Intrigues in Tanzania: The Question of Muslim Stagnation in

Education. http://www.islamtanzania.org/nyaraka/Elimu2.html

Shura ya Maimamu Tanzania. (2009). Muongozo kwa Waislamu. https://groups.google.com/forum/?fromgroups=\#!topic/wanabidii/OHhOWhJcvGo

Tambila, K.I. (2006). 'Inter-Religious Relations in Tanzania.' In Justice, Rights and Worship: Religion and Politics in Tanzania, edited by Rwekaza Mukandala et al., 57-69. Dar es Salaam: E\&D Limited.

Tanner, N. (2012). Islam and Christianity in Tanzania: The Relationship between the ReligiousMinorities of 
http://www.samuelkullmann.ch/Samuel_Kullmann/Publikationen_files/Islam\%20and\%20Christianity\%20in\%20

Tanzania\%20- \%20Essay\%20on\%20Muslim\%20Minorities.pdf

TCF. (2012). Tamko Rasmi. Raia Mwema, December 26. http://www.raiamwema.co.tz/tamko-la-tanzaniachristian-forum-tcf

TCF. (2013). Tamko la Pamoja la Mkutuno Mkuu wa Dharura wa Jukwaa la Wakristo Tanzania.

http://www.wavuti.com/4/post/2013/03/tamko-la-pamoja-la-mkutano- mkuu-wa-dharura-wa-jukwaa-lawaktristo-tanzania.html\#ixzz2PsKd23b5

TCF Mbeya. (2013). Tamko Rasmi la Jukwaa la Wakristo Mkoa wa Mbeya. http://www.jamiiforums.com/jukwaa-la-siasa/403579-tamko-la-jukwaa-la-wakristo- mkoa-wa-mbeyatcf.html

TEC\&CPT. (2009). Ilani: Mapendekezo ya Viapaumbele vya Kitaifa. http://www.forums.mwanakijiji.com/showthread.php?894-Nyaraka-za-Kanisa-Katoliki-kuelekea-UchaguziMkuu-2010\&p=11651\#post 11651

Westerlund, D. (1997). Christian-Muslim Relations in Africa: The Cases of Northern Nigeria and Tanzania Compared by Lissi Rasmussen. Journal of Religion in Africa, 27, Fasc. 4, Religion in Madagascar II: 439-441. 
The IISTE is a pioneer in the Open-Access hosting service and academic event management. The aim of the firm is Accelerating Global Knowledge Sharing.

More information about the firm can be found on the homepage:

http://www.iiste.org

\section{CALL FOR JOURNAL PAPERS}

There are more than 30 peer-reviewed academic journals hosted under the hosting platform.

Prospective authors of journals can find the submission instruction on the following page: http://www.iiste.org/journals/ All the journals articles are available online to the readers all over the world without financial, legal, or technical barriers other than those inseparable from gaining access to the internet itself. Paper version of the journals is also available upon request of readers and authors.

\section{MORE RESOURCES}

Book publication information: http://www.iiste.org/book/

Academic conference: http://www.iiste.org/conference/upcoming-conferences-call-for-paper/

\section{IISTE Knowledge Sharing Partners}

EBSCO, Index Copernicus, Ulrich's Periodicals Directory, JournalTOCS, PKP Open Archives Harvester, Bielefeld Academic Search Engine, Elektronische Zeitschriftenbibliothek EZB, Open J-Gate, OCLC WorldCat, Universe Digtial Library, NewJour, Google Scholar

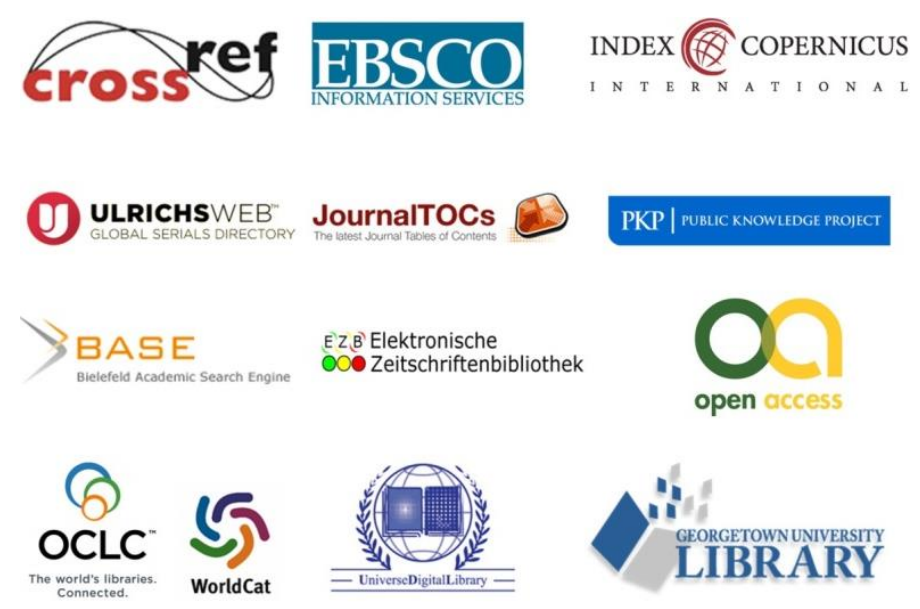

